\title{
Can Corporations Experience Duress? An Examination of Emotion-Based Excuses and Group Agents
}

\author{
Sylvia Rich ${ }^{1}$ (우
}

Published online: 20 April 2018

(C) The Author(s) 2018

\begin{abstract}
This article considers the question of whether corporate entities can benefit from the criminal-law defence of duress. The excuse of duress is accorded in recognition of the defendant's extreme fear of a threatened consequence, and it is unclear whether corporate entities — as distinct from their members - can experience fear. Many proponents of corporate rationality deny that corporations can have emotional states. I argue that corporations can experience the fear that is necessary to ground a claim of duress, but that the law should only allow fear to excuse coerced corporate action in a narrow set of circumstances.
\end{abstract}

Keywords Corporate agency $\cdot$ Corporate defences to crime $\cdot$ Duress $\cdot$ Corporate emotions

\section{Introduction}

As subjects of criminal law, it is open to corporations to argue that they should benefit from available defences if they are found to have committed a prohibited act. It seems unlikely that a corporate entity could benefit from such human-specific defences as insanity or lack of capacity. ${ }^{1}$ Other defences, such as mistake of fact, might be more plausibly applicable to corporations. ${ }^{2}$ Very little has been written

\footnotetext{
1 Though for an argument on diminished capacity of certain corporate entities, see Carlos Gómez-Jara Díez, "Corporate Criminal Liability in the Twenty-First Century: Are All Corporations Equally Capable of Wrongdoing?" (2011) 41 Stetson Law Review 41.

2 François Tanguay-Renaud, "Puzzling about State Excuses as an Instance of Group Excuses" in R.A. Duff et al. (eds.), The Constitution of the Criminal Law (Oxford University Press 2013) 119 at 131.
}

Sylvia Rich

sylvia.rich@mail.mcgill.ca

1 Ottawa, ON, Canada 
about whether or which criminal law defences apply to corporations, ${ }^{3}$ and it is possible that some would be found to be logically incoherent with the nature of a corporate entity, though by default all defences are open to all defendants. In this article, I consider whether duress, an excuse to crime committed out of fear of harm if one refuses, could apply to corporations. There is a practical dimension to this issue: the number of corporate prosecutions has been increasing in recent years in most jurisdictions and particularly in the U.S. This makes it increasingly likely that corporations will claim defences such as duress, and it will be useful to have prior theoretical consideration of the issue for judges to consult when the arguments are brought.

Duress is a defence in which defendants claim they should not be convicted of crime on the basis that they were threatened with harm to themselves or their family members if they refused to commit the crime. Criminal defences are usually separated into two categories: justifications and excuses. Justifications are cases in which conduct that is usually wrongful is rendered correct by unusual circumstances. Excuses are cases in which the conduct is still wrongful, but the law accords a partial or total excuse in recognition of circumstances that made it unusually difficult for defendants to comply with the law. Duress can perhaps best be understood as a hybrid, that is, it is sometimes a justification and sometimes an excuse, depending on whether the coerced person chose the course that minimized harm overall. ${ }^{4}$ The cases where defendants chose the lesser evil are also cases where the justificatory defence of necessity would apply, and so raising duress is redundant in those cases. A duress case where bank robbers kidnap the child of the bank manager so she will help them open the vault is a case where duress is justificatory. On the other hand, helping the Nazi government produce a chemical that will help them commit mass murder in gas chambers out of fear of harm to one's children is likely not a justification: the risk of harm to the individuals' children risks less harm than the risk incurred by handing over weapons of mass murder to mass murderers. ${ }^{5}$ In this second scenario, duress could still apply as an excuse, based on the excusatory principle that the law ought not hold someone to such superhuman standards of courage as to defy the Nazis even when they hold his child hostage. ${ }^{6}$ The cases where duress provides an excuse rather than a justification are the cases that I address in this paper.

\footnotetext{
${ }^{3}$ Ibid. at 124: "The question of the availability of excuses to non-state organizations, such as private corporations, is also notoriously under-theorized."

${ }^{4}$ On the hybridity of duress, see, for example, Suzanne Uniacke, "Emotional Excuses" (2007) 26 Law and Philosophy 95 at 110 . Alternately, one could arrive at a similar result by following Mitchell Berman's use of duress to refer only to situations where "the defendant acted in the face of substantial pressures but did not choose the lesser evil." Mitchell N. Berman, "Justification and Excuse, Law and Morality" (2003) 54 Duke Law Journal 1 at 6, footnote 9.

${ }^{5}$ This example is based on the historical case of IG Farben, explained in more detail below in Section 2.

${ }^{6}$ There are, however, limits to the application of duress. It would not excuse someone shooting 10 other children to save his child. Different jurisdictions will formulate the exceptions differently, but typically duress does not excuse murder or treason. For an example of exclusions to the application of duress, see Canada's Criminal Code (R.S.C. 1985, c. C-46) at s. 17. Note that in Canada these exceptions only apply to the principal to the crime, whereas other parties to the crime may rely on the more expansive common law excuse of duress (R. v. Hibbert [1995] 2 S.C.R. 973).
} 
The excuse of duress is based on the presence of a fear so great that it supersedes the actor's usual moral reasoning. ${ }^{7}$ We would not accept someone saying, "I was not scared for my child, but I rationally concluded that her life was worth more than that of the thousands of people who would likely be put to death in the gas chambers with my help." That thought process should not result in a successful defence. Contrast this with a person who says, "I was so terrified of this immediate threat to my child's life that I felt I had no choice but to hand over the chemicals, even knowing that they might be used to commit mass murder." In the second case, we don't find the conduct justified, but it is at least morally plausible to say that the agent is not of the kind the criminal law ought to punish.

It is unclear whether the corporate agent-as distinct from its members-can experience fear. It is uncontroversial that individuals will benefit from duress in appropriate circumstances to offences committed in the course of their employment, including offences that they commit on behalf of a corporation. ${ }^{8}$ It is entirely unsettled, however, whether the corporation itself would benefit from the same excuse in the same circumstances. Many proponents of corporate agency and corporate responsibility deny that corporations can have emotional states. In this article, I argue that corporations can indeed experience the fear that is necessary to ground claims of duress, but that the law should only allow this fear to excuse coerced corporate action in a very narrow set of circumstances.

In order to make out this argument, I begin in Sect. 2 by explaining the relationship between the emotions and duress, and then provide an account of how corporations could be understood to experience emotions. This leaves untouched the issue of how the law should respond when corporations act from fear. In Sect. 3, I address the normative question of whether there are specific features of corporations that should lead the law to create a separate set of standards for when an excuse is made out in the case of a corporation. Corporations are entities that persist because of the choice of individuals to act together as a group agent. There are both ontological and normative reasons that an agent made up of individual member agents will be able to avail itself of the excuse of duress less frequently than individuals would: ontologically, individual members retain agency, so where the fear that the organization faces is not very pervasive, there is more opportunity for the organization to resist duress in a robust way than an individual might have. Additionally, because the state grants organizations the right to exist and pursue goals with certain privileges, it is legitimate for it to hold the agent to a higher standard than it holds an individual

\footnotetext{
7 See, for instance, R.A. Duff, "Criminal Responsibility and the Emotions: If Fear and Anger Can Exculpate, Why Not Compassion?" (2015) 58 Inquiry 189; John Gardner, "The Logic of Excuses and the Rationality of Emotions" (2009) 43 Journal of Value Inquiry 315; Christopher Bennett, "Excuses, Justifications and the Normativity of Expressive Behaviour" (2012) 32 Oxford Journal of Legal Studies 563; Andrew Simester, "On Justifications and Excuses" in Lucia Zedner and Julian V. Roberts (eds.), Principles and Values in Criminal Law and Criminal Justice: Essays in Honour of Andrew Ashworth (Oxford University Press 2012) 95; and Tanguay-Renaud (supra footnote 2).

8 That is to say, individuals will benefit from these excuses in cases where the excuse of duress is not specifically barred by the law of the jurisdiction: for instance, Canada's Criminal Code at s. 17 excludes several crimes, including treason, from the application of the excuse.
} 
with natural frailties. Nevertheless, it is possible to imagine realistic cases in which the fear and corresponding duress would be so pervasive as to ground a defence for the entire corporation. For this reason, the defence should have a high threshold, but be open to corporate agents in the right setting.

\section{Duress and Corporate Fear: The Ontological Question}

Duress allows a defendant to plead that she acted out of fear for her safety or that of someone close to her and thus did something criminally wrongful, but that it was not blameworthy for her to have exhibited a weakness of will (and violated the law) given her fear. The basis of the excuse is that the law allows an exception for people who act wrongly when under the sway of very powerful fear, as long as powerful emotions are a reasonable response to their circumstances. Extreme fear in reaction to a threat to one's life is an example of when a powerful emotional response is the reasonable response, which then could excuse a certain amount of wrongdoing. In this section, I will show how a corporation can, descriptively, be under the sway of the necessary fear to experience duress.

While judges shy away from explicitly talking about duress as an emotion-based excuse and refer instead to such ideas as moral involuntariness, the idea that it is fear that gives the excusatory force to these coerced acts has a strong grounding in criminal law theory. ${ }^{9}$ If we accept this philosophically well-supported understanding of duress, then in order to be under duress, a corporation would have to be in the grips of a great fear.

It is often accepted that corporate agents have desires and related intentions (for instance, the desire and intention to make a profit). Yet desires come from some motivation, and that motivation is hard to describe in terms that do not reduce to some kind of emotional state. There is nevertheless a great deal of resistance to the idea that corporations can have emotions. Emotions require a type of subjective experience that does not come to the fore when talking about rational decisionmaking of the type that is usually privileged in our understanding of corporate entities. Feelings, the argument goes, including possible physiological sensations that accompany them, cannot reside anywhere in the group, and therefore the group cannot have emotions. ${ }^{10}$ The solution that I work out in some sense sidesteps the question, and argues instead for a supervenience theory of corporate emotions: they exist independently of individual emotions but are constituted by them. The emotion is held at the group level in the same way that an intention is held at the group level, while the neurons used to power cognition remain with the individuals.

\footnotetext{
9 See footnote 7 above.

${ }^{10}$ For example, Stephanie Collins rejects corporate phenomenal emotions, while arguing that collective agents can have a functional equivalent to emotions. Stephanie Collins, "'The Government Should Be Ashamed': On the Possibility of Organisations' Emotional Duties" (forthcoming; https://doi. org/10.1177/0032321717739553) Political Studies 11.
} 
An adaptation of a historical case from Nazi Germany provides one compelling example of when a group might feel the fear necessary to ground a duress claim. IG Farben was a German company that aided the Nazis in committing atrocities leading up to and during World War II. ${ }^{11}$ It was a large conglomerate that was already established in the business of manufacturing chemicals and other products before the Nazis came to power. Under the direction of the Nazis, the company tested out poisons on live subjects in concentration camps. It used slave labour from the camps and built a factory next to Auschwitz so that it could more efficiently make use of the slave labour available there, and it produced synthetic fuel and rubber that were important in the Nazis' war of aggression. The company was also the patent-holder of Zyklon B, a chemical that was invented and used as a pesticide but became the poison used for mass murder in Nazi gas chambers, as well as being the major owner of the company that supplied much of the Zyklon B to the death chambers. After World War II, the directors of IG Farben were tried criminally as part of the subsequent Nuremberg Trials. At trial, the directors of the company claimed that they acted out of fear that if they did not do as the Nazi officials wanted, they and their families would be harmed. The court deemed this to be a reasonable fear and a sufficient excuse for the majority of the crimes for which they were being tried. ${ }^{12}$

It is not hard to imagine corporate executives who wanted to resist this murderous regime, but participated in fear that they would otherwise be harmed or killed. Executives of this company would be properly described as acting out of fear. But what of the corporation in whose name they acted?

My starting point in discussing group agency is the idea that well-formed groups can become unitary rational agents with relatively stable existence, such that they can be held accountable for their actions. A group forms an agent if it is able to maintain rational unity and consistency over time, holding and adapting beliefs, and acting on those beliefs, in a manner similar to an individual rational agent. There is now a wide and growing philosophical literature on this conceptualization of unitary collectives (such as business corporations) as rational and moral agents. ${ }^{13}$ There is much less consensus, however, on the existence of collective emotions.

Christian List and Philip Pettit take it as a basic truth about collectives that they can have desires and intentions, such as the desire to make a profit or the intention to influence an election. ${ }^{14}$ But desire is no less a mental state than fear is. Why then is it harder to think of collectives as experiencing fear than it is to think of them as

\footnotetext{
11 Florian Jessberger, "On the Origins of Individual Criminal Responsibility under International Law for Business Activity: IG Farben on Trial" (2010) 8 Journal of International Criminal Justice 783.

12 The excuse was labelled as "necessity" in the trials but it is equivalent to what the common law now calls "duress." The directors were not acquitted, however, on their decision to build a factory adjacent to Auschwitz so that they could make most efficient use of the slave labour therein. Ibid. 791-793.

13 See, for instance, Michael Bratman, "Shared Intention" (1993) 104 Ethics 97; Margaret Gilbert, Sociality and Responsibility: New Essays in Plural Subject Theory (Rowman and Littlefield 2000); Christian List and Philip Pettit, Group Agency: The Possibility, Design and Status of Corporate Agents (Oxford University Press 2011). As Elisabeth Pacherie notes, "In the last decade, there has been an explosion of interest among philosophers and cognitive scientists alike in the topic of joint action." Elisabeth Pacherie, "How does it feel to act together?" (2014) 13 Phenomenology and the Cognitive Sciences 25 at 25.

14 List and Pettit ibid. at 26 and elsewhere.
} 
having desires? Is it because fear and other emotions appear to have a physiological aspect, the "pangs and twinges," as Margaret Gilbert calls them? ${ }^{15}$ I want to defend the idea that pangs and twinges are part of fear, and defend the idea that collectives can have fear, but not that collectives independently have pangs and twinges associated with emotions. This view is consistent with the idea that corporations have functional but not phenomenal emotional states, but I believe it is not identical with that view. ${ }^{16} \mathrm{I}$ am saying that corporations have emotional states, but am being reductionist to the extent that I admit that the emotional state has its components in the emotions of individuals, and that these components are where the phenomenal experience of the emotion resides. This view is less stringent about the reality of corporations than some other proposals about the existence of group emotions: it does not require that there be some kind of meta-individual group activity. ${ }^{17}$ What exists collectively may still be a phenomenal emotion, but its phenomenology is dependent on that of the individual members, just as the corporation's more cerebral mental states are so dependent, while being separable. The fact that the collective is separate does not mean that it is independent. ${ }^{18}$ The collective can be a separate entity with its own goals and desires, which will sometimes be distinct from those of many of its members, and those goals and desires include emotional goals and desires, not just rational goals and desires.

In order to explore the concept of corporations having emotions at the group level, I adapt the discursive dilemma that List and Pettit use as a means of showing that corporate rational agency is independent from that of its members, and is not simply a short-hand way of referring to an aggregate of individuals. ${ }^{19}$ A corporation, We Love This (WLT), forms to create a website whose purpose is to promote things that WLT loves. The three members of WLT want to promote things that they love, and only things that they love. They worry that they may not always be able to tell whether they love something, so they come up with three criteria for being in love with something: one feels happy when one is seeing it (including seeing on a screen), one is sad when it leaves or is taken away, and one desires its happiness. One day, WLT votes on whether they love a movie actor, Ray. Member A feels happy when she watches Ray's movies, and she is sad when Ray's scenes are over, but she in fact wishes for Ray to have a misfortune in his life in the near future, because she enjoys watching movie actors fall from grace. Individually she does not love Ray. Now, member B has more tortured feelings about Ray. Something about the way Ray acts makes B melancholic (so, not happy) but he also feels sad

\footnotetext{
15 Margaret Gilbert, "Collective Guilt and Collective Guilt Feelings" (2002) 6 Journal of Ethics 115.

16 On functional versus phenomenal emotions, see Collins (supra footnote 10); on functional versus phenomenal consciousness, see Christian List, "What is it Like to be a Group Agent?" (2016) Noûs 1 at 5-7.

17 In contrast, for example, Hans Bernhard Schmid, "The feeling of being a group: Corporate emotions and collective consciousness" in Christian von Scheve and Mikko Salmela (eds.), Collective Emotions (Oxford University Press 2014) 1.

18 List and Pettit talk about the group agent being epistemologically but not ontologically independent (supra footnote 13 at 76). I find this to be a prevarication and that it is better to come clean and say the agent is autonomous but not wholly independent.

19 List and Pettit ibid. at 45-46.
} 
when the movie with Ray in it ends, so he does satisfy condition 2 . He also strongly wishes for Ray to be happy and have a good life. Satisfying conditions 2 and 3 only, individually member B also does not have all the elements of love for Ray. Member $\mathrm{C}$ feels happy when she watches Ray, and she wishes good things for him, but when she's not seeing Ray she doesn't feel sad, since there are many other actors she likes just as much. She satisfies conditions 1 and 3, but not 2, and therefore also does not love Ray.

The membership votes on whether to devote a page on the WLT website to Ray. They vote as follows:

\begin{tabular}{llll}
\hline & A & B & C \\
\hline Happy to see Ray & Yes & No & Yes \\
Sad when Ray goes & Yes & Yes & No \\
Wishes Ray well & No & Yes & Yes \\
\hline
\end{tabular}

A majority of the members are happy when they see Ray, sad when they cannot see Ray, and wish good things for Ray. Therefore, on WLT's majoritarian, premisebased voting model, the collective loves Ray, although no individual member loves Ray. All the members feel something close to love, and each member genuinely feels some component of love for Ray. But love is a composite of various emotions (for simplicity's sake, I have reduced it to three, though love likely comprises more emotions than this). ${ }^{20}$ The group emotion supervenes on the individual emotional and cognitive states of happiness, sadness, and well-wishing. And so it is not an artificial decision that makes WLT love Ray, but a natural result of the feelings of its members combined with their joint intention to act as collective.

The point of this example is not to say that corporations are likely to vote on components of emotions in order to hold them at the group level, but merely to push the intuition that groups have means of holding emotions at a group level and can differentiate between individual and group emotions. Mostly, emotions will be held by the group as a side effect of the group's activities together, not because the emotional state is one of the group's desired outcomes. Emotions may be auxiliary to decisions on other issues. For instance, if the majority of a corporate group votes to spend the entire yearly marketing budget on a Superbowl ad to ridicule their competitor because they are angry that the competitor did something to embarrass them, then that is a decision fueled by anger. The vote wasn't explicitly on what emotions the company should hold, but the adoption of a corporate emotion was implicit in the vote, since it would have been more profit-maximizing to spend the money on more effective and varied marketing tools, and it was the emotion that caused them to go against their rational corporate interest.

\footnotetext{
${ }^{20}$ Unsurprisingly, there are many theories about what love is and how best to describe it. For a general overview of love as a complex of emotions, see Bennett Helm, "Love," The Stanford Encyclopedia of Philosophy (Fall 2017 Edition), Edward N. Zalta (ed.), URL $=<$ https://plato.stanford.edu/archives/fall2 017/entries/love/> (last accessed October 15, 2017) at 5.2, "Love as Emotion Complex".
} 
When does fear become strong enough to ground duress? Consider two further companies. For the purposes of the example, I have reduced the corporate decisions to a series of five-member board of directors' votes for simplicity, but the examples could be scaled up to a more complex case, and these examples also lend themselves to consideration of more fluid and organic decision-making. Suppose there is a company, Guns Ltd., whose five-member board of directors is scheduled to vote on whether to enter into a contract to sell weapons to a criminal gang. Out of five members of the board, three of them plan to vote no for ethical reasons, and two plan to vote yes. However, the night before the vote, members of the criminal organization kidnap the child of one of those who planned to vote no, threatening to kill the child if the member doesn't change his vote. The member changes his vote, and the corporation decides to sell the weapons to the criminals, by a 3-2 vote. Has the company acted under duress in this case? A majority of those who voted yes (two of the three yes voters) did not vote out of fear, so there was a significant corporate trend towards voting yes without any element of fear. There is certainly a but-for argument to make that the corporation did indeed act under duress: without the board member's fear that his child would be killed, the decision would have gone the other way, and the corporation would not have committed the criminal act. One member of the group was being coerced. Given that pressure is a matter of degree and not an all-or-nothing concept, it is fair to say that if one member with sway within the collective is under pressure, then the whole collective is under at least some degree of pressure. But given that the question at issue here is whether it is fair to describe the corporate entity as having acted under duress, the answer has to be no. When a corporation was so close to the line on entering into a criminal activity as this, and when the majority of those who voted yes did so out of greed rather than fear, it is unpersuasive to say that the corporation as a whole might be excused on the basis that it was fear that drove its action. Fear was a minority component of the action, not the main motivator.

This resolution in the negative, however, immediately prompts a question as to a further scenario, not so different from the last one, where the answer could be the opposite. Suppose there is a similar company, The Right Guns, with the same decision before it, and a similar voting set-up: five directors must vote on whether the company will sell weapons to a criminal organization. In this case, however, the criminal organization finds out that the corporation is mostly made up of lawabiding members. Of the five, only one member is greedy enough to want to make the deal to put weapons in the hands of criminal killers. The criminal organization therefore kidnaps family members of two out of the four remaining board members. Both members change their votes, giving the contract a three-member majority. Here, not only is it true that the company would not have signed the contract without coercion (as was also true in the previous example), it is also the case that duress was the dominant contributing reason that the contract was signed. This makes a crucial difference. In this case, it is descriptively correct to say that the corporation acted out of fear.

A possible objection to this argument is that it makes overly fine distinctions: there is insufficient difference between the scenario of Guns Ltd. and the scenario of The Right Guns to make one a punishable crime and the other a case of duress. 
It is uncomfortable to have a $50 \%+1$ type rule for whether fear is dominant and an excuse to crime is made out. However to make out the descriptive element of duress, dominance makes a meaningful, though sometimes subtle, difference. This is true for individuals as well. Let's say Anne offers Judy the possibility of participating in an armed robbery. Judy has always wanted to participate in a robbery, but she says she'll think about it. Anne then offers to give Judy guitar lessons as an extra incentive (Judy wants these lessons). Judy is now almost certain she's going to say yes. But Anne, not knowing this, gets worried that Judy isn't going to participate, and tells Judy she will stab her in the stomach with a knife if Judy doesn't help. Judy finds this scary, and believes Anne would stab her. Judy says yes and they commit the armed robbery together. Judy should not be able to successfully claim duress here. She experienced some coercive pressure, and it's possible that she might ultimately have backed out without it, but it wasn't her dominant motivation for agreeing to join in the robbery.

One difference in the individual case is that we cannot apportion percentages to each motivation as neatly. It is possible that Anne has five motivations to act in a certain way, but one of them is so strong as to eclipse the others. Still, on the issue of whether duress is made out as far as the descriptive element is concerned, the guiding principle is the same for the corporation and the individual: we have cases in which an emotion, while present, is not the dominant reason for action, and cases in which it is. We also have borderline cases, or cases in which we will be reluctant to say with certainty which motivator is dominant. In the next section, I will further this argument by suggesting that, while Right Guns is descriptively a case of fear being dominant, it does not meet the objective test for duress, because corporate groups have the ability and therefore the responsibility to maintain further checks on corporate action emanating from illegitimate motives, including fear.

Another potential objection to this solution on corporately held fear is that the fear cannot become part of the corporation if it is never publicly communicated within the corporate membership. In an IG Farben-type case, it would have been commonly understood that the members of the company would put themselves and their families at risk if they disobeyed Nazi requests for assistance. Even if they did not speak of their fear, that fear would be common knowledge because the situation they were in was common knowledge, and that understanding would pervade group meetings and other interactions. In the case of the two gun-selling companies, things are somewhat different. External forces have put pressure on members of the corporation individually, and the response of the members would likely be not to tell anyone about their fear, as silence would be a condition imposed by the threatener. Therefore, not only would these emotions not be subject to a vote, they wouldn't even be discussed.

Given that not all individual emotions become corporate simply because a member of the group holds them, what distinguishes certain individually held emotions and allows them to become part of the corporate makeup even when they are not openly communicated within the group? It is their functional role within the corporation-i.e., whether they affect the corporation's actions. Corporate emotions will often be a side effect of the corporation's existence, rather than one of its intended effects. So, a corporation could be racist without explicitly having decided to be 
racist, and corporation could also be jealous of its competition as in the advertising case above, without it being part of the corporation's initial intentions. These effects need not be part of the corporation's goals or ever be openly discussed to be true features. They would be features because the corporation would behave in ways consistent with those attitudes, thus making the presence of the emotion a factor that changes the corporation's ethos. Consider greed as a corollary here. Greed is an emotion that is often attributed to corporations, and is experienced by members as part of the corporate culture in certain organizations. ${ }^{21}$ I do not need to communicate my greed, but if I am greedy and I act out of greed when I make corporate decisions and my fellow members sense this, it will embolden them to act similarly, and together we will shift the corporation towards a greedier disposition. ${ }^{22}$ The same is true of other emotional states: they have their effects, whether or not they are explicitly voiced. One might also think of these as akin to a felt but unacknowledged emotion in an individual, for instance, when a person is in denial about being scared of something, but experiences and acts from this fear nonetheless.

What we are looking for here is emotions that explain corporate actions, rather than those that reside exclusively in the private domain. Emotions can drive intentions when they are unspoken as easily as when they are spoken. The corporation as a whole will vote yes to deal arms to the criminal organization, creating a corporate intention to sell guns to criminals. The individual voting members intend to do this variously because of greed and because of fear. Would it make more sense to say that the corporation intends it because of its general background motivation of financial gain? Of course, the company is in business to make a profit, but it is a terrible over-generalization to substitute that as the motivation for every single thing it does. It seems much more descriptively accurate to acknowledge the reality of its various emotional motivations. These have their source in individual minds-as does the corporation's profit motive. Just like the company's profit motive, emotional states such as love and fear take on a collective dimension when they operate within the corporation.

The corporation's agency and its emotional states supervene on those of its membership. Corporate emotional states are not directly reducible to the emotions of the membership, but are influenced by them. Though corporations can experience fear, they will experience it less intensely than an individual in a similar situation is likely to, except in a case where the fear acts on a majority of members. Individuals who

\footnotetext{
${ }^{21}$ Greed is not as clearly within the centre of what we mean by "emotion" as fear or anger, but it has similarities: it is characterized by feeling, it can come and go from one's mind, it can often be triggered by external stimuli (such as seeing something one desires), and it changes one's dispositions and attitudes when one is under its sway. As such, I think it has enough claim to be emotion-like to be a useful analogy to corporate fear. William James was also of the opinion that greed is an emotion. William James, "What is an Emotion?" (1884) 9 Mind 188.

22 This phenomenon is similar to the phenomenon that scholars call the "risky shift," whereby members of a group will take more risks in the group than they would take individually. Susanna K. Ripken, "Corporations are People Too: A Multi-Dimensional Approach to the Corporate Personhood Puzzle" (20092010) 15 Fordham Journal of Corporate and Financial Law 97 at 132 . Ripken also describes how loyalty to a group will lead members to continue to act in ways that are clearly not working well or that disturb their consciousness (ibid).
} 
are not subject to duress have more sway over the rest of the membership than do the parts of Judy's individual psyche that are not subject to the duress that she experiences because of Anne's threats. The members in the organization who are not individually subject to duress still have power to steer the organization away from the offending behaviour, even if they must break usual protocols (such as abiding by the decision that the board reaches by vote) to achieve this.

The collective's fear does not reside in some mind that is separate from the minds of its members. The fear that motivates the decision arises in some individuals, and will spread to others through emotional contagion, the (empirically observed) phenomenon in which the presence of an emotion in some members of a group will increase the likelihood of it appearing in others: so people get swept up by their neighbours' fear, their classmates' anger, their friends' laughter, and so on. ${ }^{23}$ The existence of a corporation creates conditions for the amplification of emotions over and above how those emotions would travel in a looser aggregate of individuals. This does not mean that the emotion must spread, but that it likely will. Consider a student orchestra where a majority of the players have a strong desire to make it to a national competition. Some of the members are indifferent, but they still come to practice three times a week and play with their fellow orchestra members. It is easy to imagine that the desire to reach the national competition would eventually infect the few indifferent players. At any rate, it is likelier that a member of this orchestra would start to aim for national competition than would a player in an orchestra where no other member was thinking about getting to nationals. In this way, there is an interplay where the individuals affect the group and the group affects the individuals.

Of course, not all members' emotions will get redescribed as corporate emotions, even if one single emotion is pervasive in the group at one time. If the experience of the emotion has no effect on the corporation's activities, then it remains a personal emotion. On the other hand, even a physiological sensation such as hunger can intrude on the group if it affects the collective's intentions and actions. If all the members of a company were extremely hungry for lunch, and they chose that moment to hold their vote on whether to commit the crime of selling guns to drug dealers, and they voted yes to committing a crime primarily because a yes vote would get them to the lunch table sooner than a no vote, then it seems to me that one could never produce a full, truthful account of why the corporation acted as it did that did not involve hunger. So, while the hunger in the case of the members' lunches might not be redescribed as the corporation's own physiological hunger, the mental state of hunger that results from that physiological sensation forms part of the mental state that is the corporation's own.

All individual members retain their own agency and have a responsibility to steer their organization towards right action to the extent that they are able to, so where the fear that the organization faces is not very pervasive, there is likely a way for the

\footnotetext{
${ }^{23}$ Elaine Hatfield, Megan Carpenter, and Richard L. Rapson, "Emotional contagion as a precursor to collective emotions" in Collective Emotions, Christian von Scheve and Mikko Salmela (eds.), (Oxford University Press 2014) 108.
} 
organization to resist letting fear become dominant in a more robust way than an individual might be able to. Where the fear is contained within a small percentage of the members of the group and other individuals have power to influence the corporation's actions, then the corporation ought to be able to overcome the fear. On the other hand, if the fear begins with a small number of individuals but spreads so that a large majority of the members that make up the corporation are in the grips of fear, then it will be difficult for the corporation to resist. In these cases, fear could become a dominant motivator of the group's actions.

\section{Corporate Duress: The Normative Element}

The criminal law is not bound treat a corporation's fear-based decisions in the same way that it does those of an individual who acted out of fear. We move now to consider what the law's response to a corporation's fear-based decision to commit a crime should be. The second element of the defence of duress is that the coerced person reacted to her circumstances in a reasonable way, which is to say within the range of ways society condones someone reacting. In offering an excuse for criminal acts committed in fear, the law is making an authoritative statement that society finds this to be a reasonable response to fear stimulus: that, as Antony Duff puts it, "this is how appropriate emotions are properly expressed". ${ }^{24}$ Fear is both reasonable and appropriate when one is threatened with immediate violence. In the Right Guns hypothetical, the corporation acted out of the appropriate amount of fear. This does not automatically entail exoneration by reason of duress. The law makes choices about when to provide an excuse. In doing so, its decision-makers should be guided by considering what makes the law most responsive to moral considerations as well as what makes it most internally consistent. For these reasons, we might want to make a different set of arguments about what the law's response ought to be when a corporation claims an excuse than when an individual does. It is open to the law to say that the proper expression of the emotion of fear is different in the case of a corporate entity, so that the self-same action by the self-same hands might give an excuse to all individuals involved but not to the corporation on whose behalf they acted. The normative question of how the law should treat its subjects can and should be sensitive to corporate structure and to the nature of groups.

While excuses should still be available to corporations in extreme cases, the voluntary nature of a corporate entity - its existence being due to the choice of individuals to come together in pursuit of an economic goal-supports the conclusion that corporations should be given less leeway to act in breach of criminal norms even when they are under the same kind of emotional pressures that accord excuses to individuals.

The choice to sustain a new and potentially powerful agent creates an extra layer of responsibility, as does the fact that the state accords companies specific rights,

${ }^{24}$ Duff (supra footnote 7) at 196. 
and in some ways those rights are greater than the rights of individuals, such as providing limited liability to members of companies for acts they commit through the group agent. Do these privileges mean that the corporation ought to face different obstacles than an individual does when raising the possibility of an excuse in criminal law $?^{25}$ As moral agents in their individual capacities, when individuals choose to constitute a new agent for the purpose of advancing their various economic or social interests, they must do so in ways that respect moral obligations. The element of choice in the creation of the corporation means that we are rightly less sympathetic to organizations when they exhibit moral flaws - individuals take on an extra moral responsibility when they choose to participate in the creation of a whole new moral agent. Additionally, when individuals join together to form a group agent, they take on a level of responsibility for their fellow members' actions that we do not expect an individual to have for the actions of other proximate individuals generally. These two points may also explain a wider social phenomenon, that people often feel angry when corporations exhibit normal human failings such as carelessness and cowardice in the sphere of organizational action. But I take it this does not mean that these failings would never be excused.

There are situations where it would be correct to say that the organization acted out of appropriate fear for the safety of a natural person, but where we should withhold an excuse. In the Right Guns hypothetical, the corporation acted under duress, descriptively speaking. There is, nonetheless, a strong reason to find that the hypothetical company would not meet the objective portion of the test. The voting members who were not under duress also form part of the company, and are quite unlike detached observers to their fellow corporate members' actions. They were involved by virtue of their membership in the group agent. At least one member acted in an entirely criminal way, intending to enter into the unlawful and harmful contract. Two others acted out of fear. And the remaining two members voted to act lawfully, but then went along with the majority's decision to commit a crime. Membership in the group, especially voting membership at the highest level, entails a responsibility for shaping the group's acts. The non-coerced members should have done more to steer the corporation towards law-abiding behaviour, including acting outside of the corporation's voting procedures if necessary.

In the case of an individual, the criminal law requires her not to offend unless the dominant reason for her offending is an overwhelming fear for her safety or the safety of a family member. If the individual is somewhat afraid but feels that it would be possible to get out of the bad situation, or that the bad eventuality is not actually so frightening, then duress is not made out. A group has many members, and these members are implicated in the group's decisions. So, the Right Guns members who voted no are still involved in the yes vote, and remain members of the corporation even when it makes the criminally wrongful decision. Because they are a part of that group, and are not under any duress themselves, they would have

\footnotetext{
25 It may be of interest to note that this argument is not limited to emotional excuses anymore, and would also apply to mistake of fact, which is an excuse that Tanguay-Renaud argues, contra Simester, should possibly be available to states: Tanguay-Renaud (supra footnote 2) at 132 and 149-150.
} 
a responsibility to stop the group of which they are members from offending. For corporate duress to succeed, there would need to be a more pervasive fear among the relevant members of the group. This need not include senior management. For instance, if someone threatens all the workers in a factory one night and out of fear they hand over explosives, knowing that the person threatening them is going to use the explosives to blow up an empty building, the fear of these factory workers would likely be enough to excuse the entire corporation, since they are the only ones who are there to make that decision at that time. ${ }^{26}$ Where the fear is pervasive enough among the members of the corporation that are in charge of the relevant decision, the fear can legitimately be redescribed as corporate fear. Normatively, a corporation would only be found to be under duress in very pervasive cases of fear.

In the most severe of cases, a corporation's decision to give into the fear of harm to natural persons closely connected to it can be reasonable. This is the set of cases in which so much of the membership is under the sway of this fear that the emotion becomes pervasive in the organization, as it would in a case like that of the Nazi-aiding IG Farben. In a situation where there is sufficiently widespread coercion through fear, the excuse is warranted, even if we hold to the line that corporate excuses should be judged more strictly than those of individuals. In these pervasive cases, the fear would be as hard to resist as it is in those cases where the law accords a defence of duress to individuals, and so it be most consistent with the logic of the criminal law to afford the excuse to corporations as well, in these extreme situations.

\section{Conclusion}

Corporations can experience emotions, including fear. For emotions to exist, they must exist somewhere. But this is also true of knowledge: for knowledge to exist, it must reside somewhere. There are subjective experiences associated with knowing something, like the flash of understanding that cartoons depict by showing a lightbulb turning on in a thought bubble. In this way, knowledge is not so different from emotions. In the case of corporate knowledge-or corporate desire or intention-the mental state resides in some configuration of its members. This can be true even though no member holds that particular mental state herself. Intentions can be the result of compromises or composites. This is also true for emotions, as I showed with the We Love This thought experiment. The emotion takes on a distinct corporate reality. There is no contradiction between accepting that group entities are real, that they have an effect and a presence that is separate from that of their members, but also accepting that everything they think, feel, and do occurs through their individual members.

One significant upshot of corporate emotions is that they have an effect on how corporations act. Corporations can be fearful, and act out of fear, much as individuals can (though with different parameters, based on the differences that arise when many individuals' separate experiences collide within an organization). Where a

\footnotetext{
${ }^{26}$ Of course, depending on the theory of corporate criminal liability to which one ascribes, the factory workers' decision might not implicate the company in the first place, but that is a separate topic.
} 
corporation is dominantly fearful to the requisite standard, it is appropriate to consider that it acted under duress. This paper makes a practical contribution to criminal law literature in delineating the circumstances in which a corporation could benefit from the excuse of duress, and so provides some possible guidance for judges who are presented with corporations claiming duress as an excuse to criminal action. While it might seem that this type of scenario would be unlikely to arise in real life, the example of IG Farben gives one clear historical case in which fear for loss of life was a serious possible motivation for criminal action. There, it was the state itself creating duress, but it is also plausible that some private entity would threaten a corporation's members to aid and abet its illegal activities. In a case of extreme and pervasive fear such as that one, the excuse should succeed assuming fear was found to be the real cause of the crime, rather than it simply co-existing with self-interest.

This paper contributes to the ongoing debate on how corporations fit into the criminal law. It also makes a philosophical contribution to the small but growing field of the study of collective emotions. The argument for the existence of corporate emotions provides an insight into how corporations are constituted that challenges some deep-rooted assumptions about corporate behaviour. Specifically, it implies that a whole range of emotions inform corporate decisions, despite corporations often being construed as paradigmatic rational decision-makers.

Acknowledgements I would like to thank John Gardner, Nicola Lacey, Rebecca Williams, Leah Trueblood, Kate West, Kezia Speirs, Ethel Saltzman, as well as an anonymous reviewer, for helpful comments on earlier versions of this article.

Open Access This article is distributed under the terms of the Creative Commons Attribution 4.0 International License (http://creativecommons.org/licenses/by/4.0/), which permits unrestricted use, distribution, and reproduction in any medium, provided you give appropriate credit to the original author(s) and the source, provide a link to the Creative Commons license, and indicate if changes were made. 